\title{
Globalising Love: On the Nature and Scope of Love as a Form of Recognition
}

\author{
Heikki Ikäheimo
}

Published online: 7 February 2012

(C) Springer Science+Business Media B.V. 2012

\begin{abstract}
This article begins by tracing two issues to be kept in mind in discussing the theme of love as far back as Aristotle: on the one hand the polysemy of the term philia in Aristotle, and on the other hand the fact that there is a focal or core meaning of philia that provides order to that polysemy. Secondly, it is briefly suggested that the same issues are, mutatis mutandis, central for understanding the discussion of love or Liebe by Hegel, the central classic reference in debates on recognition. Thirdly, by pointing out a certain ambiguity in Harry Frankfurt's recent work on love, the article focuses more closely on the thought that love in the simple sense which Aristotle had pinpointed as the focal meaning of philia, which is arguably at the core of Hegel's discussion of Liebe, and which still forms at least one of the core senses of the term, is a 'personifying' attitude of recognition. Finally, drawing on the above points the article addresses the question whether love as a form of recognition is restricted to intimate relations such as those between family-members, 'lovers', close friends and so on, or whether it has applications in interhuman relations more broadly. The answer to this question, it is suggested, is essential for the viability of ethically substantial notions of solidarity beyond circles of close acquaintances, whether within the civil society, across nations, or towards future generations.
\end{abstract}

Keywords Aristotle $\cdot$ Daniel Brudney $\cdot$ Harry Frankfurt $\cdot$ Hegel $\cdot$ Love $\cdot$ Solidarity

\section{Introduction}

There are a great variety of phenomena called 'love', many ancient words translated by this one word, and various, often incompatible philosophical definitions.

H. Ikäheimo $(\square)$

Philosophy, Faculty of Arts and Social Sciences, University of New South Wales,

Sydney, NSW 2052, Australia

e-mail: h.ikaheimo@unsw.edu.au 
Whichever of the more exact senses of the word one has in mind, conceiving it properly requires accounting for a rich constellation of other closely related phenomena-some of which may also go by the same name. The theory of recognition introduces one particular way of thinking about love, namely as a form of recognition — or more technically, as a species of the genus 'recognitive attitude'.

In this article I will begin by tracing two issues to be kept in mind in discussing the theme as far back as Aristotle. These are, on the one hand the polysemy of the term philia in Aristotle, and on the other hand the fact that there is a focal or core meaning of philia that provides order to the polysemy. Secondly, I argue briefly that the same issues are, mutatis mutandis, central for understanding the discussion of love or Liebe by Hegel, the central classic reference in debates on recognition.

Thirdly, by showing that there is a certain ambiguity in Harry Frankfurt's recent work on love, I focus more closely on the thought that love in the simple sense which Aristotle had pinpointed as the focal meaning of philia, which is arguably at the core of Hegel's discussion of Liebe, and which still forms at least one of the core senses of the term, is a 'personifying' attitude of recognition. Love in the sense in question is concern for someone's happiness for his or her own sake.

Fourthly, drawing on the points made so far I focus on the question brought up in recent work on recognition-namely whether love as a form of recognition is restricted to intimate relations such as those between family-members, 'lovers', close friends and so on, or whether it has applications in interhuman relations more broadly. On the one hand, the idea of loving people whom one does not know personally is faced with a conceptual problem pointed out by Daniel Brudney. On the other hand, this idea seems necessary for ethically substantial notions of solidarity beyond circles of close acquaintances, whether within the civil society, across nations, or towards future generations.

The question whether it is possible to consistently conceive of love as a form of recognition beyond close circles of acquaintances thus not only concerns the limits of application of one of the major elements of recognition-theory, but also the real world applicability of the concept of solidarity. I end by casting doubt on Brudney's way of trying to solve the impasse, and propose very briefly another solution that warrants further investigation.

\section{Complications with Philia}

Aristotle's efforts in reconstructing the meaning of the Greek term philia involve a certain ambiguity or polysemy which it is useful to examine in order to see clearly how similar ambiguities play out in contemporary ways of thinking and talking about love. There are two different issues that Aristotle-following the everyday word use of his day-calls philia. First, there are the famous three forms of philia: pleasure-philia, utility-philia, and philia between good men qua good (Aristotle 2001a, Book VIII). ${ }^{1}$ Of these, Aristotle suggests that the third is philia 'firstly

\footnotetext{
$\overline{1}$ References to Aristotle are given by Bekker number.
} 
and in the proper sense' and the two others only 'by analogy' (Aristotle 2001a, 1157a31).

But secondly, there is something that according to Aristotle is the 'focal' meaning of the word. ${ }^{2}$ This, as he writes in the Rhetoric, is 'wishing for [someone] what you believe to be good things, not for your own sake but for his' (Aristotle 2001b, 1380b37; see also 2001a, 1166a3-1166a5). What is potentially confusing here is that the first of the three phenomena called philia on the one hand, and philia in what Aristotle thinks is the focal meaning on the other hand, are categorially different kinds of things.

To clarify this, let us introduce a simple threefold distinction between

(1) concrete interpersonal relationships, involving both psychological and other elements,

(2) complexes of interpersonal attitudes and other closely related psychological phenomena such as emotions and sensations involved in (1), and

(3) single interpersonal attitudes etc. comprising (2).

Whereas pleasure-philia, utility-philia, and philia between the good are different kinds of (1) concrete interpersonal relationships, what the focal meaning of philia refers to is (3) a single interpersonal attitude. As any concrete interpersonal relationships, the three kinds of philia-relationships involve different kinds of (2) complexes of attitudes that the parties to a relationship have with regard to each other. ${ }^{3}$ In any individual relationship, many of the attitudes (as well as emotions and sensations related to these) are particular to that relationship. Yet, some of them are characteristic or defining of the kind of relationship that it is. Aristotle's classification of the three types of philia-relationships mentioned is based on focusing in each case on one interpersonal attitude that provides the primary reason for engaging and staying in a relationship, and in this way defines it as of the kind it is.

Or not quite. What I have just said is true of pleasure-philia where the defining attitude is that of valuing (or perhaps one should say desiring) the other because of her qualities that the subject finds pleasurable, as well as in the case of utility-philia where the defining attitude is that of valuing the other because of her qualities that the subject finds useful (Aristotle 2001a, 1156a6-1156b6). Yet, the situation is more complicated with regard to the philia-relationship between the good. In several passages Aristotle distinguishes this from the two other philia-relationships by saying that in philia between the good partners care about each other's good or wellbeing for the other's own sake, whereas in utility- and pleasure-philia they only care about it for the sake of gaining pleasure or utility for themselves (Aristotle 2001a,

\footnotetext{
2 See Vlastos (1973, pp. 4-5). 'Focal meaning' is Vlastos's translation (owed to G. E. L. Owen) of Aristotle's phrase pros hen legomenon that Aristotle uses in defining philia (Aristotle 1984, 1236a16-1236b27). Aristotle does not use this phrase in talking about the philia-relationship between the good.

3 What I want to signal with the word 'concrete' is that concrete relationships are not reducible to psychological or 'subjective' factors, but always also involve various kinds of 'objective' factors or elements, such as interconnected social and institutional roles and various kinds of physical factors.
} 
1156a6-1156a22). ${ }^{4}$ Hence there is good evidence to think that this attitude-caring about the good, well-being or happiness ${ }^{5}$ of the other for her own sake (or as I shall say in short, caring, or being concerned, about the other unconditionally ${ }^{6}$ )—is what defines the philia-relationship between the good. Yet, there is another attitude that most interpreters tend to think is the defining element of these relationships.

Clearly, when partners in a relationship are good or virtuous, they not only unconditionally care about each other's well-being (this is what good people do according to Aristotle ${ }^{7}$ ), but they also (at least tend to) value each other for their virtuous qualities (Aristotle 2001a, 1156b15-1156b18.). Thus there is in fact a complex of interrelated interpersonal attitudes comprising of mutual unconditional concern for the other, and mutual cherishing of the goodness or virtuousness of the other (part of which is his unconditional concern for one), that together form the characteristic psychological profile of the philia-relationship between the good. ${ }^{8}$ There does not seem to be any obvious answer to the question whether caring about the other unconditionally, or valuing the goodness of the other, is the primary reason why good men engage in these kinds of philia-relationships, and in this regard they are a more complex affair than relationships based on pleasure or utility on Aristotle's idealizing or ideal-typifying description.

Unfortunately Aristotle does not make an explicit theme of the distinction between unconditional concern or care ${ }^{9}$ for the other on the one hand and valuing the other for her virtuous (or other) qualities on the other hand, but leaves this to the reader. A failure by the reader to adequately think through the elements of the philia-relationship between the good in their difference and interrelations easily leads to confusion, such as the view that Aristotle actually failed to have a clear concept of caring about someone's well-being or happiness 'for her own sake', i.e. regardless of her qualities, at all, making it rationally dependent on the object of love having virtuous qualities that the subject appreciates. ${ }^{10}$ This is clearly wrong since where Aristotle actually discusses the focal meaning of philia-the attitude of unconditional care for the other-he is perfectly explicit that this is rationally

\footnotetext{
${ }^{4}$ See lines 1156a9-1156a10: 'wish well to each other in that respect to which they love one another'); 1156b9: 'wish well to their friends for their sake'; and 1168a32: 'the good man acts [...] for his friend's sake'.

${ }^{5}$ I use these terms interchangeably. 'Happiness' is however here the key term since of the three only it makes explicit that the objects in question are beings with perspectives, and moreover with perspectives of possible happiness or misery-which is to say persons.

6 'Intrinsically' is a term often used in this context and I have used it as well in previous work. It has however unfortunate associations with the notion of 'intrinsic value' that I want to avoid here to emphasize the difference between personifying care or concern on the one hand and valuing on the other.

${ }^{7}$ See note 4 .

${ }^{8}$ Other accompanying psychological phenomena-attitudes, emotions and sensations-are of course involved as well, but they will vary more from case to case.

${ }^{9}$ I use these terms interchangeably in this paper.

${ }^{10}$ According to Vlastos, Aristotle did not have even an 'inkling' of the notion of unconditional concern for the other (Vlastos 1973, p. 33). This is a startling claim, considering that Vlastos is otherwise clear enough on the focal meaning of philia in Aristotle, but it is understandable as a consequence of the confusion to which I am drawing attention.
} 
unconditioned by the qualities of the beloved. ${ }^{11}$ His paradigmatic example is a mother's attitude towards her infant, where the infant does not at first even have virtuous qualities (including the philia-attitude towards her parents) (Aristotle 2001a, 1159a28-1159a33; 1161b26-1161b28). Aristotle is also clear that this very same attitude is present in philia-relationships between the virtuous (but not in the two other kinds of philia-relationships he discusses). Although in such relationships it belongs to a complex of interpersonal attitudes which also involves the attitude of valuing the other for his goodness or virtuousness, it is not true that the parties in such relationship only care about each other's happiness because they value each other's goodness or virtuousness (or any other qualities for that matter). In fact, this would be self-defeating since an element of what it is to be good in Aristotle's view is, as I have said, to care about others for their own sakes, i.e. regardless of their qualities.

All in all, in Aristotle's reconstruction there is $a$ focal meaning of philia, namely the attitude of caring about someone's good, well-being or happiness unconditionally or 'for her own sake', and this, in his view, is a necessary (but not the sole) element of the attitude-complex characteristic of relationships that primarily deserve the name philia. If Aristotle failed in something in his reconstruction of the thematic complex that the many senses of philia referred to, then it was in not clearly communicating all of the relevant distinctions to his readers. ${ }^{12}$

\section{Caution with Liebe}

For Hegel, the central classic reference in recognition-theory, it is as important in reading his treatment of the theme of love or Liebe as it is in reading Aristotle's treatment of philia to be clear about the threefold distinction above. ${ }^{13}$ If it is possible, Hegel is generally speaking even less explicit about it than Aristotle. This is understandable given the central ideas that provide the context within which Hegel discusses the theme of Liebe more or less throughout his intellectual career. ${ }^{14}$ Hegel's view is, in the spirit of conceptual realism and normative essentialism, that there are structures of reality that empirical phenomena instantiate as their essences, and that these structures are normative criteria for the phenomena. In the realm of 'spirit' - the human life-form that is - the structure most fundamental of all is that of 'finding oneself in one's other', which in brief means for Hegel a structure of overcoming alienation and in this sense achieving 'unity', while at the same time

\footnotetext{
11 Rationally independent means that the qualities do not provide reasons to love or not to love. This does not rule out that they could play some causal role in the coming about or fading of love.

12 One might of course complain also about Aristotle's choice to accept the word-usage of his day in using the term philia 'by analogy' even for relationships based on pleasure or utility, which—on his own description-do not involve philia in the focal sense at all. Whereas the connection between philia on the focal sense and the philia-relationship between the good that I have pointed out provides justification for the practice of calling these by the same term, the nature of the 'analogy' remains thereby still unclarified.

13 Williams (2010) is useful in pointing out analogies between Aristotle's treatment of philia and Hegel's treatment of Liebe, yet it suffers from lack of clarity exactly on this distinction.

14 The best monograph length treatment of Liebe in Hegel that I know of is Werner (2007).
} 
retaining difference. This, on Hegel's account, is the overarching normative principle of social life, the degree of whose instantiation in tokens of social life is decisive for their ethical quality. ${ }^{15}$ Hegel conceived early on in Tübingen of love or Liebe as an instantiation of this structure, ${ }^{16}$ and later on in Jena and thereafter recognition becomes the central concept in terms of which Hegel talks of its instantiations. In the latter stage, however, love remains in the picture as one of the forms of recognition. ${ }^{17}$

The main thing that interests Hegel in his discussions of Liebe is that it is, as he sees it, an instantiation of the structure in question. He is usually not particularly careful in specifying when he means by Liebe a concrete relationship, a complex of attitudes (and other psychological phenomena), or a single attitude, since all of these can be meaningfully thought of as instantiations of 'finding oneself in one's other'. Other distinctive features of Hegel's treatment of the theme of Liebe include his explicit emphasis on sexuality, as well as his later focus on the bourgeois nuclear family as the institutional setting of Liebe.

All in all, there is a rich constellation of issues at stake in Hegel's discussion of Liebe and-even more so than Aristotle with the constellation of issues he calls philia-he leaves it for the reader to think through its internal structure. In order to do so properly, it is essential to distinguish between

1. concrete interpersonal relationships, especially (but not only) ${ }^{18}$ those within the bourgeois nuclear family between the spouses on the one hand and between children and their parents on the other, involving not only attitudinal and other psychological or 'subjective' elements, but also institutional, physical and other 'objective' elements,

2. the complexes of interpersonal attitudes and other psychological phenomena involved in the different concrete relationships, and finally

3. single interpersonal attitudes, emotions etc. comprising the different complexes. For example, sexual desire is one such attitude that belongs to some complexes but not to others.

There is no space to argue this here, but I have elsewhere tried to show that there is one attitude that is essential in how exactly the constellation of issues that Hegel calls Liebe instantiates the structure of 'finding oneself in one's other', an attitude that thereby forms the core of all relationships and all attitude-complexes that deserve the name Liebe in Hegel. ${ }^{19}$ This is the attitude of unconditional concern for

\footnotetext{
${ }^{15}$ For more on Hegel's normative essentialism and the basic principles of his Philosophy of Spirit, see Ikäheimo (2011).

16 See for example Hegel: 'love [...] finds itself in other people' (1984, p. 46).

${ }^{17}$ For the view that the notion of recognition has an important presence in Hegel's work not only in but also after Jena, see Williams (1997).

18 Here and there Hegel mentions friendship (Freundschaft) as an instantiation of 'finding oneself in the other'. See for example Hegel (1971, p. 176 [\$436]).

19 See Ikäheimo (2011) where I argue that one needs to have this concept of love in mind if one is to make sense of how exactly love as a form of recognition can fulfil all the functions that it has in Hegel, or in other words to see how exactly it instantiates the structure of 'finding oneself in one's other'.
} 
the good, well-being or happiness of the other-the very same attitude that is on Aristotle's view the focal meaning of philia. ${ }^{20}$

\section{Love as Personification}

I believe there is overwhelming evidence that what Aristotle over two millennia ago thought of as the focal meaning of philia and what around two centuries ago was at the core of Hegel's treatment of Liebe is also today at least one of the core senses of 'love' (and its equivalents in at least most European languages), if not the core sense. ${ }^{21}$ It is also what Axel Honneth mostly understands by love as a form of recognition in his seminal work on the theme - and in my view rightly so. There are some passages in Honneth, however, where the phenomenon in question-caring about someone's happiness for her own sake-gets confused with valuing someone for her qualities. ${ }^{22}$ Yet, confusion between the various attitudes comprising typical or characteristic attitude-complexes in the relevant kinds of concrete relationships is less characteristic of Honneth's writing as it is of the work of some other authors of interest for the themes of love and recognition.

Importantly, Harry Frankfurt's in many ways insightful recent treatises on the theme of love eventually suffer from a fundamental unclarity on the very concept at stake. Discussing the specific kind of unclarity in Frankfurt helps us to thematize the essentially interpersonal nature of love as a form of recognition. In Taking Ourselves Seriously Frankfurt defines love as a 'particular mode of caring', namely an 'involuntary, nonutilitarian, rigidly focused [...] self-affirming concern for the existence and the good of what is loved'. That loving is non-utilitarian means for Frankfurt that it is caring about the beloved 'for its own sake' (Frankfurt 2006, p. 40). In loving the lover does not care about the 'existence or good' of the beloved from the point of view of his or her own individual interests (of pleasure, utility,

\footnotetext{
${ }^{20}$ What interests me here is more the internal logic of Hegel's thinking about love, and less whether every detail of what he wrote is actually consistent with this logic. Yet, one can test the thesis that this attitude is the 'core' in the sense of a necessary element of everything that Hegel himself calls Liebe by finding passages where he talks about Liebe in a systematic sense where this is not the case on a plausible reconstruction. Things are somewhat complicated though by Hegel's commitment to normative essentialism which allows that phenomena can instantiate their essences to different degrees. This means that in principle relationships or attitude-complexes can count as Liebe to different degrees, depending on the relative significance of the attitude in question in them.

21 A common objection to defining love as caring about the good, well-being or happiness of someone for her own sake is that this is an abstract and bloodless notion of love foreign to the real life complexityand according to the romantic objector, passion — of love. But here one should ask whether the objector has in mind concrete relations, complexes of attitudes etc., or single attitudes. Concrete relationships can be very complex indeed and the same is true of attitude-complexes. And often, but not always, these involve passionate emotions and sensations. Yet, if one asks for one single criterion on which to decide whether there is or was real or genuine love in a relationship, or whether a complex of attitudes etc. between partners in a relationship really also includes or included love, then the attitude at stake is a very strong candidate.

22 See Honneth on the 'uniqueness' of the loved one for the loving person that is a function of 'the unique way' in which her 'qualities come together' (2007, p. 167). For sure, something like this is quite often very important for the attitude-complexes involved in love-relationships. Yet, it is a different matter to claim that it is essential to them. I abstract here from Honneth's treatment of relations of love in Honneth 2011, pp. 252-276.
} 
etc.), but rather internalizes 'the interests of the beloved as his own', and thus unconditionally, without conditioning by his own separate interests, 'benefits when his beloved flourishes' and 'suffers when it is harmed' (Frankfurt 2006, p. 41).

All this sounds reminiscent of Aristotle's focal meaning of philia, as well as of Hegel's idea of Liebe as finding oneself in the other; yet there is a decisive difference between Frankfurt on the one hand and Aristotle and Hegel on the other. Frankfurt thinks that the object of love can be 'almost anything - a life, a quality of experience, a person, a group, a moral idea, a nonmoral idea, a tradition, whatever' (Frankfurt 2006, p. 40). This is something Aristotle would never have thought of philia, nor Hegel of Liebe, both thinking of the phenomenon in question as an essentially interpersonal one. I believe there is good reason for them to do so.

Arguably, Frankfurt's basic failure is that he does not distinguish between the attitude of unconditional concern or 'care' in an essentially interpersonal or 'personifying' sense on the one hand, and that of valuing in a not essentially interpersonal sense on the other hand. The all important difference between these is that the former is not a matter of valuing its object at all, but rather of valuing from the perspective of the object-which obviously involves taking the object as a being with a perspective.

Beings with perspectives are called subjects, and subjects with perspectives of the relevant kind-in short, perspectives that make it possible for the subject to experience happiness or misery-are persons. To care about x's happiness or subjective well-being unconditionally, which is to say to see the world in evaluative terms from his perspective of possible happiness and misery, thus involves taking $\mathrm{x}$ as a person. In contrast, to value $\mathrm{x}$ does not necessarily involve taking $\mathrm{x}$ as a person.

Frankfurt's indistinction between these in his talk of 'love' obfuscates the obvious fact that talking about the 'interests', 'good', or 'sake' of the beloved take on very different meanings depending on whether one takes the beloved as a person with a subjective perspective of possible happiness or misery, or whether one takes the beloved as some other type of entity altogether, such as a quality or idea. It is also a very different matter to suffer, on the one hand, when ones beloved suffers, because in loving him or her one sees the world in evaluative terms (partly) from his or her perspective and thus immediately subjectively benefits or suffers when (one thinks) she does, and to suffer, on the other hand, when, say, an idea one values or endorses (or 'really loves', to speak loosely) is generally misunderstood and in this way 'harmed'.

Frankfurt is of course free to ignore this distinction—one which on my reading is already implicitly present in Aristotle and Hegel even if they never spelled it out loud and clear-and the confusing consequences that doing so may have on his own account of personhood are not our topic here. In thinking about love as a species of the genus recognitive attitude, however, it makes all the difference. This is assuming, as I have argued elsewhere (e.g. Ikäheimo 2007), that all of the recognitive attitudes are 'personifying' attitudes, or attitudes the having of which involves, or is, taking the object as a person. One way to see the point of following the strong formula that love as a recognitive attitude is a way of taking the other as a person is this: in valuing things from the beloved's perspective one relates to her in light of similar practical person-making significances in light of which one (in nonpathological cases) relates to oneself. 
One formulation of the point in question is 'someone whose happiness or wellbeing is unconditionally important', which is to say important in the same way in which a person's own happiness or well-being is normally important for herselfunconditioned by its importance for others. ${ }^{23}$ But since it is the flourishing or perishing of what has value for a person that is the source of her happiness or misery, another formulation for the same is something like 'an irreducible perspective of value'. The beloved's perspective of possible happiness and misery is a measure of value for the lover irreducible to anyone else's perspective, including the lover's own thought of as separate from the beloved's. In other words, the beloved's interests become the lover's interests unconditionally, without being conditioned by his own separate interests-just as a person's own interests are his interest unconditionally, without being conditioned by the separate interests of any others. ${ }^{24}$ Having $\mathrm{x}$ in view in light of such practical, immediately motivating significance-whether $\mathrm{x}$ is oneself or another-is, I suggest, one of the most fundamental ways of having $\mathrm{x}$ in view as a person. ${ }^{25}$ It is one of the 'personifying' recognitive attitudes that are essential to the being of persons as persons.

This also makes good sense of Aristotle's famous and enigmatic thought that a friend (philos) is 'another self' (Aristotle 2001a, 1166a31), ${ }^{26}$ as well as of Hegel's closely related idea that persons can find themselves in each other in Liebe. That is, the other who loves me is 'another me' in the sense that the perspective from which she values things and states of affairs includes my perspective in a way unmediated by further evaluations, and this means that I can really 'find myself', in the sense of my concerns, immediately affirmed by her perspective of concern and thus 'in her'. Both ideas find consummation in mutual love, but even here the core phenomenon is love itself as the simple attitude of unconditional concern for the other.

\footnotetext{
${ }^{23}$ This is not to deny that a person can also care about his happiness because of its importance for others. If you love me, my happiness is part of your happiness, and if I also love you, I do not want to make you unhappy by making myself unhappy.

24 This does not rule out that I have separate interests that are in conflict with my beloved's interests that are also my interests because I love her. It only rules out that her interests are my interests merely because of my separate interests. In other words, as Hegel always emphasized, the unity brought about by love does not annul difference.

25 The recognitive attitude of respect is another fundamental way. What I am suggesting is that 'personmaking' significances in light of which an object of recognitive attitudes is revealed to their subject are significances the applying of which to $\mathrm{x}$ is having particular kinds of motivations towards $\mathrm{x}$. Call this motivational internalism about taking someone as a person. I am trying to elaborate here on a theme that Honneth mentions with regard to Dewey's idea of the significance 'man' as having 'a qualitative effect' (2008, p. 40). In my view, Arto Laitinen's critical reconstruction of 'taking x as a person' (Laitinen 2011) misses this internalist point.

26 See also Vernon L. Provencal's deeply Hegelian—even if Hegel is nowhere mentioned in the articlediscussion of the theme, developing the thesis that the idea of self-relation (through others) is fundamental to Aristotle's ethics (Provencal 2001). In light of Provencal's reading Hegel and Aristotle are very close to each other indeed.
} 


\section{The Scope of Love}

It is very widely thought-not only but also in recognition-theory-that love is restricted to intimate relations such as those between family-members, erotic 'lovers', close friends and so on. ${ }^{27}$ Whether it is right to think so is a question of importance for recognition-theory since it concerns the limits of application of one of its major elements. But it is also of quite general importance to ask whether it is really impossible to love people beyond a close circle of acquaintances. ${ }^{28}$ There are three general ways in which one might be led to think that this is obviously so-corresponding to the threefold distinction made above-each of which are in different ways, so to say, out of focus.

One is identifying love with concrete interpersonal relationships of a kind that are by their nature limited to small circles. For example, it is obvious that the concrete ways in which one is related to one's own family-members do not extend beyond the family. I am not everyone's son, brother, spouse, father or uncle, with all the biographical, social, institutional and other particularities that being a son etc. involves.

The second way is identifying love with attitudinal complexes of a kind that are by their nature limited to small circles. The complex of attitudes and related emotions and sensations that one has, say, with regard to one's spouse or 'lover' tends to be rich, complicated and intense and there are obvious limits to having anything comparable towards almost anyone else, not to mention people who one does not know well or at all. This is even more obviously, or trivially, so if one identifies love with complexes comprising of the relevant intertwining attitudes etc. of both partners in a close relationship. Nothing of the sort of psychological intimacy involved here is possible between people who know each other poorly or not at all.

The third way is by confusing individual attitudes, emotions or sensations, or having the wrong ones in mind. If one identifies love with, say, sexual desire for a person, with longing for or enjoying life-companionship with him or her, or with the various phenomena that go by the name 'attachment', it does not take much to realize that each of them comes with obvious limits of reach. The same goes for identifying love with emotions (say, particular forms of happiness or

\footnotetext{
27 Aristotle himself at one point says that one can only have eunoia ('goodwill'), but not philia, with regard to (a) people whom one does not know, as well as towards (b) people who do not know about one (2001a, 1166b30-1166b32). But Aristotle does not explain why (a) is the case, and he contradicts himself with (b), since he elsewhere talks about the philia of mothers towards their children whom they have given away to be brought up elsewhere and who therefore do not know their mothers (2001a, 1159a28-1159a33).

28 There has recently been much interest in applying the Honnethian recognition-theoretical paradigm in global issues. For articles prompting theorists to think about love as a form of recognition beyond the intimate sphere of the family or other close relationships, see Heins (2008) and Thompson (forthcoming). Thomas Lindemann (forthcoming) argues powerfully for the significance of 'empathy' between nations in pacifying international relations and of 'lack of empathy' in encouraging armed conflicts. Honneth (2010) has recently suggested that it is not feasible to distinguish between different types of recognition in the explanation of the dynamics of international relations. I am more optimistic that the differentiated conception of recognition, pioneered by Honneth himself, can be very illuminating also in global applications of the paradigm.
} 
jealousy) that can only emerge when attitudes of the kind just mentioned are present; or with some occurrent sensations of a kind one can only ever have with regard to people one is very close to.

However, if one identifies love with what already Aristotle thought of as the focal meaning of philia, what was arguably the core of Hegel's discussion of Liebe, what still today is at least one of the core senses of 'love', and what I suggest we should understand by love as a recognitive attitude - the personifying attitude of unconditional concern for someone's happiness - then all of these ways of coming to the conclusion that love cannot extend beyond circles of people psychologically very close to each other are simply beside the point. They are not talking about the right phenomenon.

But what about the right phenomenon then? Can one have love in the sense of personifying unconditional concern for strangers? Let me take up one candidate reason to think we cannot that looks especially challenging and that has been put forth in recent work on recognition. In an article on the young Marx's conception of 'true communist society' Daniel Brudney comes to the conclusion that Marx's societal ideal of non-alienated production-as producing for others out of love for them-is, literally speaking, conceptually incoherent beyond a social context in which it is possible for producers to personally know the consumers. Why? Because on Brudney's view love as a concern for well-being requires individuated objects, and unknown consumers remain 'altogether unindividuated' (Brudney 2010, p. 160) for the producer. According to Brudney, the same objection applies generally to the idea of loving people en masse-say 'billions of unknown, distant others' (Brudney 2010 , p. 161). Brudney does not, however, see this necessarily as a serious problem for what Marx was after, nor for the idea of ethical relations with distant, unknown others generally, since all that is needed for reclaiming these is replacing the concept of love with the concept of 'concern'. For concern, as Brudney understands it, does not require individuated objects (Brudney 2010, p. 161).

I see a potential problem here. This stems from the possibility that in being concerned about the well-being of people in a way which is not individuating one is being concerned about them in a way which is also not personifying. What is it after all that distinguishes what Brudney means by 'concern' for the well-being of unknown other people from the non-personifying kinds of concern one could normally have for the well-being of, say, the rain-forests of Sumatra? If nothing, then I believe Brudney's suggestion fails to reclaim what the young Marx was after. Marx namely thought it essential that in a communist society producers and consumers 'relate to each other as humans' (Brudney 2010, p. 166; Marx 1975, p. 447 $)^{29}$ - which I believe is best reconstructed as relating to each other in terms of attitude-complexes that involve taking each other as persons. As Brudney observes, love is indeed fundamental in such complexes for the young Marx, and this suggests that he may be committed to the thought that love is at least necessarily accompanied by, if not simply is a form of, personification of its objects.

\footnotetext{
${ }^{29}$ I have replaced 'men' with 'humans' to translate the original 'Menschen'. What Marx means by a 'human relation' is on my reconstruction a concrete relationship in which recognitive, and thus personifying attitudes have an adequate role.
} 
But not only is a non-personifying concern for people arguably an inadequate reconstruction of what the young Marx was after, as the only or predominating attitude towards people it is also commonsensically insulting, often humiliating, and ethically deeply problematic. For sure, in being in serious need of help from others one might prefer being the object of their non-personifying concern to not being an object of their concern at all—say, being saved from starvation by benefactors whose only motive is to profit from the ones whom they decide to raise above starvation as cheap labour. Similarly, if the alternative is unappealing enough, one might prefer being saved by benefactors who see oneself, or the group in which one belongs, as an object with 'intrinsic value' - just as someone may (at least claim to) see, say, the Sumatran rainforests, the biosphere, or particularly beautiful, interesting or rare pieces of art, as valuable, not (at least merely) for the sake of something else but 'intrinsically', and thus as something that should be salvaged from destruction or dereliction. ${ }^{30}$

Yet, in being valued instrumentally or 'intrinsically,' one is not thereby an object of personifying, unconditional concern for happiness or subjective well-being, nor is one thereby seen in light of any other person-making significance either. Neither of these attitudes is as such a personifying attitude and neither of them necessarily even implies the presence of personifying attitudes-or of recognition-that is. ${ }^{31}$ And to the extent that one is the object of attitude-complexes that lack the personifying attitudes of recognition, one is, I take it, being reified or thingified. ${ }^{32}$

Why is this important? One of the many reasons is the following: assuming that the idea of solidarity — in any ethically substantial sense-implies personifying, or non-reifying concern for the happiness or well-being of the relevant others, the impossibility of having such an attitude towards unknown others means that the idea of solidarity between people who are not intimately connected is stillborn. Solidarity on the level of large modern societies is a contradiction in terms, the idea of global solidarity even more so-not to mention the idea of solidarity for future generations. All nothing but sentimental nonsense. Are they, really? Is it really the case that the best that people personally unknown to each other can expect from each other in terms of concern is to be cared about either instrumentally, or then in some other sort of non-personifying, reifying way?

I do not think so, and considering the implications to the idea of solidarity I doubt that most ethically serious people are willing to think so either. Assuming that they are right, the philosophical task is to show how personifying, unconditional concern-love that is - for distant or unknown others is possible. There is no space to develop the theme at any length here, but let me make a short comment about one possible direction of further inquiry. What may be the decisive issue is the role of imagination in our concrete relationships to others who are unknown to us, or who

\footnotetext{
30 Think of, for example, aestheticizing versions along the lines of 'they are such strange and beautiful people ... strange and beautiful things are intrinsically valuable ... therefore they should be conserved'. There is a familiar form of cultural fetishism that has undertones of this sort of aesthetist reification of people of other cultures.

31 Esteem, or as I prefer to call it 'contributional valuing', is a more complicated matter. See Ikäheimo and Laitinen (2010).

32 This should go to show that ignoring this distinction, as Frankfurt seems to do, is not a trivial matter.
} 
we know poorly. ${ }^{33}$ What we are not personally acquainted with, we tend to fill in with products of our imagination, and these are (ideally) placeholders for what we could, or may, learn in real encounter. ${ }^{34}$ As it is of decisive significance for our relations to others in real interpersonal encounters whether, or to what extent, we see the others in light of person-making significance (or they us), it is also of decisive significance for imagining others whether, or to what extent, one imagines or construes them in light of person-making significance. ${ }^{35}$

To the extent that our actions affect the lives of others unknown to us personally, a question of major practical, political and ethical importance is how we imagine those others, or how we construe the imaginary others that in our minds hold their place. Even if it is impossible to individuate and thus personify unknown others, individuating and personifying imaginary others is not-and this may be the decisive phenomenon. Even imagining a large group of persons personally unknown to oneself as a group of persons must, it seems, involve imagining (at least some representative) individuals in light of person-making significances. Raimond Gaita gives a good example of imagining others without enough of this: a western woman watches a television documentary about Vietnamese mothers whose children were killed in bombing raids, and comments 'But it's different for them, they can simply have more' (Gaita 1999, pp. 57-60). What I am thus suggesting is that the key notion for rationally reconstructing the idea of ethical relations of solidarity towards distant or unknown others, and thereby salvaging it from all too easy refutation or cynic ridicule, may not be that of loving strictly speaking, but of imagining lovingly.

Acknowledgments I thank Daniel Brudney for a fruitful exchange on the topics of this paper. If I understand him right, his fully articulated position may in fact be compatible with what I am proposing here. My thanks are also due to Simon Thompson for helpful comments.

\section{References}

Aristotle, 1984. Eudemian ethics. In The complete works of Aristotle, ed. Jonathan Barnes, 1922-1981. Princeton: Princeton University Press.

Aristotle, 2001a. Nicomachean ethics. In The basic works of Aristotle, ed. Richard McKeon, $298-548$. New York: The Modern Library.

Aristotle, 2001b. Rhetoric. In The basic works of Aristotle, ed. Richard McKeon, 1317-1451. New York: The Modern Library.

\footnotetext{
33 It should not require further arguments that all people living on the finite earth are connected with each other in innumerable concrete ways, such as through actions that affect the earth's biosphere, through the global economy, and so on.

34 Another direction perhaps worth further investigation is the idea of attitudes towards personally unknown others to which one is inferentially committed. On this, see Ikäheimo 2004.

35 Think of the ways one can be moved, or unmoved, by the fates or fortunes of literary figures. Now think of your own imagination as the 'author'. What I am suggesting is that a dimension of imagining something as a person involves viewing things from his or her irreducible perspective of happiness and misery. The other dimension to do with respect and authority cannot be discussed here. See also Richard Rorty on 'human solidarity' requiring the capacity to see 'strange people as fellow sufferers' or 'as one of us' (Rorty 1989, p. xvi). If introducing the phenomenon of imagination here seems somehow weak or irrelevant, just consider the idea articulated by Benedict Anderson and others that political communities are essentially 'imagined communities'. How individuals and collectives imagine each other and their relations is essential to how these relations are and how they will develop.
} 
Brudney, Daniel. 2010. Producing for others. In The philosophy of recognition, ed. Hans-Christoph Schmidt am Busch, and F.Zurn Christopher, 151-188. Lanham: Lexington Books.

Frankfurt, Harry. 2006. Taking ourselves seriously and getting it right. Stanford: Stanford University Press.

Gaita, Raimond. 1999. A common humanity. Melbourne: Text.

Hegel, G.W.F. 1971. Hegel's philosophy of mind. Oxford: Clarendon.

Hegel, G.W.F. 1984. Three essays, 1793-1795. Notre Dame: University of Notre Dame Press.

Heins, Volker. 2008. Realizing Honneth. Journal of Global Ethics 4: 141-153.

Honneth, Axel. 2007. Love and morality. In Disrespect, 163-181, ed. Axel Honnth. Cambridge: Polity Press.

Honneth, Axel. 2008. Reification: A new look at an old idea. Oxford: Oxford University Press.

Honneth, Axel. 2010. Anerkennung zwischen Staaten. In Das Ich im Wir, ed. Axel Honneth, 181-201. Berlin: Suhrkamp (English translation in Lindemann and Ringmar 2011).

Honneth, Axel. 2011. Das Recht der Freiheit. Berlin: Suhrkamp.

Ikäheimo, Heikki. 2004. Analyzing social inclusion in terms of recognitive attitudes. In Social inequality today: Proceedings of the 1st annual conference of the CRSI, eds. Michael Fine, Paul Henman and Nicholas Smith. Macquarie University, http://www.crsi.mq.edu.au/public/download.jsp?id=10598.

Ikäheimo, Heikki. 2007. Recognizing persons. Journal of Consciousness Studies 5-6: 224-247.

Ikäheimo, Heikki. 2011. Holism and normative essentialism in Hegel's social ontology. In Recognition and social ontology, eds. Heikki Ikäheimo, and Arto Laitinen, 145-209. Leiden: Brill.

Ikäheimo, Heikki, and Arto Laitinen. 2010. Esteem for contributions to the common good: The role of personifying attitudes and instrumental value. In The plural states of recognition, ed. Michel Seymour, 98-121. Basingstoke: Palgrave.

Laitinen, Arto. 2011. Recognition, acknowledgement and acceptance. In Recognition and social ontology, eds. Heikki Ikäheimo and Arto Laitinen, 309-347. Leiden: Brill.

Lindemann, Thomas. Forthcoming. Concluding remarks on the empirical study of international recognition. In The struggle for recognition in international relations, eds. Thomas Lindemann and Erik Ringmar. Boulder, CO: Paradigm.

Marx, Karl. 1975. Comments on James Mill. In Marx-Engels collected works, vol. 3, 211-228. New York: International Publishers.

Provencal, Vernon L. 2001. The family in Aristotle. Animus 6: 3-31, http://www.swgc.mun.ca/animus. Accessed 26 December 2010.

Rorty, Richard. 1989. Contingency, irony and solidarity. Cambridge: Cambridge University Press.

Thompson, Simon. Forthcoming. Recognition beyond the state. In Global justice and the politics of recognition, eds. Tony Burns and Simon Thompson. London: Palgrave Macmillan.

Vlastos, Gregory. 1973. The individual as object of love in Plato. In Platonic studies, 2nd revised. ed. Gregory Vlastos, 3-34. Princeton: Princeton University Press.

Werner, Laura. 2007. The restless love of thinking: The concept of Liebe in G.W.F. Hegel's philosophy. Helsinki: Helsinki University Press.

Williams, Robert R. 1997. Hegel's ethics of recognition. Berkeley: University of California Press.

Williams, Robert R. 2010. Aristotle and Hegel on recognition and friendship. In The plural states of recognition, ed. Michel Seymour, 20-36. Basingstoke: Palgrave. 